DOI: https://doi.org/10.31933/jimt.v2i3

Received: 21 November 2020, Revised: 28 Desember 2020, Publish: 16 Februari 2021

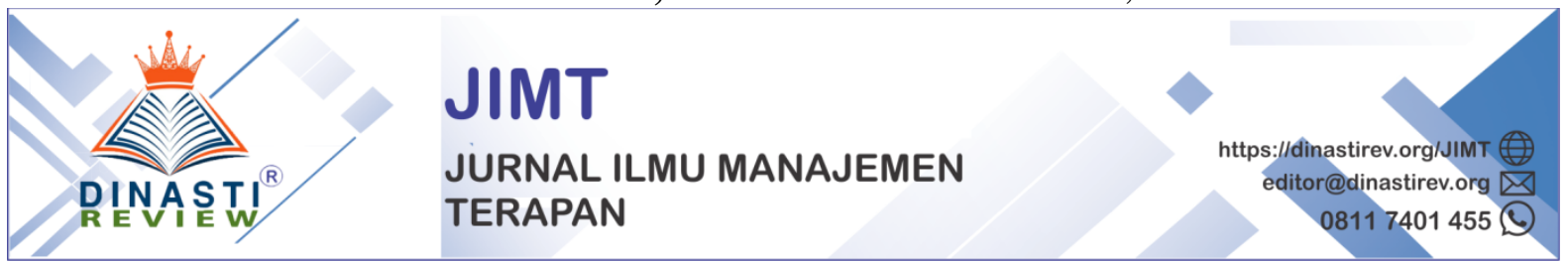

\title{
ANALISIS RASIO KEUANGAN PT. SURYA SEMESTA INTERNUSA TBK DENGAN INDUSTRI BUILDING CONSTRUCTION YANG TERDAFTAR DI BURSA EFEK INDONESIA PERIODE 2014-2019
}

\author{
Fery Erwanda ${ }^{1}$ \\ 1) Universitas Mercu Buana, Jakarta, Indonesia, feryerwanda@gmail.com
}

Corresponding Author: Fery Erwanda ${ }^{1}$

Abstrak: Penelitian ini dilakukan untuk mengetahui dan menganalisis kinerja keuangan pada PT. Surya Semesta Internusa Tbk yang dibandikan dengan total industri dengan menggunakan analisis rasio keuangan dan analisis $d u$ pont. Data yang digunakan adalah laporan keuangan periode 2014 -2019 yang terdaftar di bursa efek indonesia dengan sub sektor building construction dengan total perushaan sebanyak 17 perusahaan. Dengan jumlah perusahaan dengan laporan keuangan yang lengkap sebanyak 12 perusahaan. Maka sampel yang digunakan pada penelitian ini sebanyak 12 perusahaan. Hasil penelitian ini diharapkan mampu menjadi acuan dan tolak ukur perusahaan dalam menilai kinerja keuangannya.

Kata Kunci: Rasio Keuangan, Du Pont.

\section{PENDAHULUAN}

Pada saat ini keuangan merupakan hal penting bagi perusahaan. Banyak perusahaan yang akan memperhatikan keuangannya terutama di dunia usaha yang semakin maju dan berkembang saat ini. Selain itu agar perusahaan dapat bertahan dan dan berkembang bahkan dapat bersaing dengan perusahaan lainnya, perusahaan harus mencermati kondisi dan kinerja perusahaan dengan melihat kondisi keuangannya

Perusahaan pada umumnya melihat kesehatan keuangannya dengan cara melihat laporan keuangannya. Laporan keuangan merupakan alat yang sangat penting untuk perusahaan, karena dari laporan yang diterbitkan oleh perusahaan merupakan sumber informasi sehubungan dengan posisi keuangan perusahaan, kinerja perusahaan dan hasil yang telah dicapai perusahaan. . Cara untuk mengetahui dengan tepat bagaimana melihat kondisi keuangan suatu perusahaan adalah dengan diperlukan suatu analisis yang tepat salah satunya yaitu dengan menggunakan analisis rasio keuangan

Menurut Kasmir (2017:7) laporan keuangan adalah laporan yang menunjukkan kondisi keuangan perusahaan pada saat ini atau dalam suatu periode tertentu. Maksud laporan keuangan yang menunjukkan kondisi perusahaan saat ini adalah merupakan kondisi terkini. 
Kondisi perusahaan terkini adalah keadaan keuangan perusahaan pada tanggal tertentu (untuk neraca) dan periode tertentu (untuk laporan laba rugi).

PT. Surya Semesta Internusa Tbk. Salah satu perusahaan yang kegiatan usaha perusahaan adalah dibidang Building \& Construction. Berikut adalah Laporan Laba-Rugi yang diperoleh oleh PT. Wijaya Karya (Persero) Tbk. selama enam tahun terakhir dari periode 2014 - 2019 yang dapat dilihat pada tabel 1 .

$\begin{array}{ccccccc}\text { Penjualan } & \begin{array}{c}\text { Tabel 1 } \\ \text { HPP } \\ (-)\end{array} & \begin{array}{c}\text { EBIT } \\ \text { Eapon Laba - Rugi } \\ \text { Biaya } \\ \text { Bunga(- }\end{array} & \begin{array}{c}\text { EBT } \\ \text { ) PPH }\end{array} & \begin{array}{c}\text { Laba Th } \\ \text { Berjalan }\end{array} \\ 4.464 & 3.410 & 578 & 130 & 531 & -16 & 516 \\ 4.868 & 3.689 & 647 & 139 & 392 & -9 & 383 \\ 3.797 & 2.728 & 441 & 181 & 93 & 8 & 101 \\ 3.274 & 2.410 & 2.029 & 243 & 1.698 & -457 & 1.241 \\ 3.682 & 2.701 & 354 & 171 & 125 & -35 & 90 \\ 4.006 & 2.915 & 420 & 177 & 165 & -29 & 136\end{array}$

Sumber: LK Tahunan PT. Surya Semesta Internusa Tbk. (https://www.idx.co.id)

\section{KAJIAN PUSTAKA \\ Pengertian Rasio Keuangan}

Salah satu cara untuk mengetahui kondisi keuangan perusahaan adalah dengan menghitung rasio-rasio keuangan yang diinginkan. Analisis rasio keuangan merupakan analisis yang banyak digunakan. Pos-pos yang terdapat dalam laporan keuangan dibandingkan sehingga memperoleh suatu rasio tertentu. Menurut Kasmir (2013:122), pengertian rasio keuangan adalah: "kegiatan membandingkan angka-angka yang ada di dalam laporan keuangan. Perbandingan dapat dilakukan antara satu komponen dengan komponen dalam satu laporan keuangan atau antar komponen yang ada diantara laporan keuangan. Kemudian angka yang diperbandingkan dapat berupa angka-angka dalam satu periode maupun beberapa periode."

Definisi rasio keuangan menurut Harahap (2013:297) adalah: "rasio keuangan adalah angka yang diperoleh dari hasil perbandingan dari satu pos laporan keuangan dengan pos lainnya yang mempunyai hubungan yang relevan dan signifikan (berarti). Rasio keuangan ini hanya menyederhanakan informasi yang menggambarkan hubungan antara pos tertentu dengan pos lainnya. Dengan penyederhanaan ini kita dapat membandingkannya dengan rasio lain sehingga dapat memperoleh informasi dan memberikan penilaian." Menurut Kieso, Waygandt dan Warfield (2011:211) rasio keuangan adalah "ratio express the mathematical relationship between one quantity and another. Ratio analysis expresses the relationship among pieces of selected financial statement data, in a precentage, a rate or a simple proportion".

Menurut Fahmi (2014:44) rasio keuangan adalah hasil yang diperoleh dari perbandingan jumlah, dari satu jumlah dengan jumlah lainnya. Sedangkan analisis rasio keuangan merupakan analisis dengan membandingkan satu pos dengan pos laporan keuangan 
lainnya baik secara individu maupun bersama-sama guna mengetahui hubungan di antara pos tertentu, baik dalam laporan posisi keuangan maupun laporan laba rugi (Jumingan, 2014:242).

\section{Jenis-Jenis Rasio Keuangan}

Jenis rasio keuangan yang digunakan dalam penelitian ini yaitu, rasio likuiditas, solvabilitas, aktivitas, dan profitabilitas (Kasmir, 2016:129-172):

\section{Rasio Likuiditas}

Rasio likuiditas (liquidity ratio) merupakan rasio yang menggambarkan kemampuan perusahaan dalam memenuhi kewajiban (utang) jangka pendek. Beberapa rasio likuiditas yang digunakan:

\section{a. Rasio Lancar (Current Ratio)}

Rasio lancar merupakan rasio untuk mengukur kemampuan perusahaan dalam membayar kewajiban jangka pendek atau utang yang segera jatuh tempo pada saat ditagih secara keseluruhan. Kasmir (2016, 134-138) rumus rasio likuiditas yang digunakan adalah:

Current Ratio $=\underline{\text { Hutang Lancar }} \times 100 \%$

Aktiva lancar

\section{b. Rasio Cepat (Quick Ratio)}

Rasio cepat merupakan rasio yang menunjukkan kemampuan perusahaan dalam memenuhi atau membayar kewajiban atau utang lancar (utang jangka pendek) dengan aset lancar tanpa memperhitungkan nilai persediaan (inventory). Kasmir (2016, 134138)

rumus rasio likuiditas yang digunakan adalah:

Quick Ratio $=\underline{\text { Aktiva lancar-Persediaan }} \times 100 \%$

Hutang Lancar

\section{Rasio Solvabilitas}

Rasio solvabilitas digunakan untuk mengukur kemampuan perusahaan untuk membayar seluruh kewajibannya, baik jangka pendek maupun jangka panajang apabila perusahaan dilikuidasi (dibubarkan) (Kasmir, 2016:151). Rasio solvabilitas dibagi menjadi beberapa, yaitu:

\section{a. Rasio Hutang Terhadap Aset (Debt to Assets Ratio)}

Rasio ini digunakan untuk mengukur perbandingan antara total utang dengan total aset. Rumus yang digunakan yaitu :

DebtRatio $=$ Total Hutang

$$
\text { Total Aktiva }
$$

b. Rasio Hutang Terhadap Ekuitas (Debt to Equity Ratio)

Rasio ini merupakan rasio yang digunakan untuk menilai utang dengan ekuitas. Rumus yang digunakan yaitu :

DebtRatio $=\underline{\text { Total Hutang }}$

Total Ekuitas

\section{c. Equity Multiplayer}


Rasio yang dapat menunjukkan kemampuan perusahaan dalam memanfaatkan ekuitas atau modal yang dimilikinya secara optimal. Rumus yang digunakan yaitu :

Equity Multiplayer $=\underline{\text { Total Aktiva }}$ Total Ekuitas

\section{d. Capital Structure}

Rasio yang dapat menunjukkan seberapa besar ekuitas atau modal yang dimiliki perusahaan dibiayai atau berasal dari hutang jangka panjang. Rumus yang digunakan yaitu:

Capital Structure $=\underline{\text { Utang Jangka panjang }}$

\section{Total Ekuitas}

\section{Rasio Aktivitas}

Rasio aktivitas merupakan rasio yang digunakan untuk mengukur efektivitas perusahaan dalam menggunakan aset yang dimilikinya (Kasmir, 2016:172). Adapun Jenis Jenis Rasio aktivitas sebagai berikut :

\section{a. Receivable Turnover}

Rasio yang digunakan untuk mengukur kualitas dan efisiensi tingkat perputaran piutang perusahaan dalam satu periode dengan membandingkan penjualan dengan rata-rata piutang. Semakin tinggi rasionya, maka semakin baik kualitas dan efisiensi perputaran piutang perusahaan

Rumus Receivable Turnover yang digunakan adalah :

Receivable Turnover $=$ Penjualan $:$ Piutang

\section{b. Day's Sales in Receivable}

Rasio yang digunakan untuk mengukur rata-rata berapa hari pelanggan membayar pembelian mereka. Rumus Day's Sales in Receivable yang digunakan adalah :

Day's Sales in Receivable $=\underline{365 \text { hari (asumsi } 1 \text { tahun) }}$

\section{Receivable Turnover}

\section{c. Inventory Turnover}

Rasio ini mengukur pengelolaan persediaan barang dagang. untuk menilai efisiensi operasional, yang memperlihatkan seberapa baiknya manajemen mengontrol modal yang ad a pada persediaan. Rumus yang digunakan adalah :

Inventory Turnover $=\underline{\mathrm{HPP}}$

\section{Persediaan}

\section{d. Day's Sales Turnover}

Rasio yang menunjukkan berapa lama waktu yang dibutuhkan perusahaan untuk menyimpan persediaan mereka sebelum dijual dan juga dikatakan bahwa rasio ini dapat menunjukkan berapa lama waktu yang dibutuhkan untuk menjual persediaan yang tersedia di perusahaan.Rumus Day's Sales Turnover yang digunakan adalah: Day's Sales Turnover $=\underline{365 \text { hari (asumsi } 1 \text { tahun) }}$

$$
\text { Inventory Turnover }
$$

\section{e. Total Asset Turnover}

Rasio ini merupakan perbandingan antara penjualan dan total aktiva suatu perusahaan, yang menggambarkan kecepatan perputarannya total aktiva dalam satu periode tertentu. Rumus Total Asset Turnover yang digunakan adalah : 
Total Asset Turnover $=\underline{\text { Penjualan }}$

Total Aktiva

\section{Rasio Profitabilitas}

Rasio profitabilitas merupakan rasio untuk menilai kemampuan perusahaan dalam mencari keuntungan. Rasio ini juga memberikan ukuran tingkat efektivitas manajemen suatu perusahaan (Kasmir, 2016:196).

a. Profit Margin

Profit Margin atau margin laba atas penjualan merupakan rasio untuk mengukur margin laba atas penjualan dengan cara membandingkan laba bersih setelah pajak dengan penjualan bersih (Kasmir, 2016:199).Rumus yang digunakan yaitu :

Profit margin $=\underline{\text { Laba Setelah Bunga dan Pajak }} \times 100 \%$

Penjualan

\section{b. Return On Asset}

Rasio ini digunakan untuk mengukur seberapa besar laba bersih yang akan dihasilkan dari setiap dana yang tertanam dalam aset. Rumus Return On Asset yang digunakan adalah :

Return On Asset $=\underline{\text { Laba Setelah Bunga dan Pajak }} \times 100 \%$

Total Aktiva

\section{c. Return On Equity}

Rasio ini menunjukkan berapa persen perolehan laba bersih bila diukur dari modal pemilik. Semakin besar semakin bagus. Rumus yang digunakan yaitu:

$\mathrm{ROE}=\underline{\text { Laba Setelah Bunga dan Pajak }} \times 100 \%$

Total Ekuitas

\section{Analisis Du Pont}

$\mathrm{Du}$ Pont System merupakan salah satu alat untuk mengukur kinerja keuangan perusahaan secara menyeluruh, karena mampu secara langsung menguraikan dua laporan pokok dari laporan keuangan yaitu neraca dan laba rugi.

Menurut (Keown, Martin, Petty, \& Scott, 2018, hal. 88) “Analisis Du Pont merupakan suatu metode yang digunakan untuk menganalisis profitabilitas dan tingkat pengembalian ekuitas." Sedangkan menurut (Najmudin, 2011, hal. 95) "Du Pont adalah salah satu sistem analisis laporan keuangan yang tersusun integratif. Metode ini menggabungkan rasio aktivitas marjin laba terhadap penjualan dan menunjukkan interaksi rasio-rasio dalam menentukan profitabilitas."

Menurut (Fraser \& Ormiston, 2018, hal. 223) "Manfaat Du Pont adalah membantu pihak yang berkepentingan untuk melihat bagaimana keputusan danaktivitas perusahaan selama perjalanan periode akuntansi yang diukur oleh rasio keuangan untuk menghasilkan keseluruhan pengembalian atas ekuitas." Analisis DuPont menggunakan rumus return on equity (ROE) yang di gambarkan sebagai berikut

\section{Analisis DuPont $=$ Net Profit Margin x Asset Turnover x Equity Multiplier}




\section{METODE PENELITIAN}

Pada penelitian ini pemilihan lokasi di PT. Surya Semesta Internusa Tbk, melalui situs resminya www.suryainternusa.com. Penelitian ini menggunakan metode deskriptif dengan pendekatan kuantitatif yang merupakan data yang berbentuk kata, skema maupun gambar dan Kualitatif yang merupakan data yang berbentuk angka atau data kualitatif yang diangkakan. Data yang digunakan untuk menganalisis adalah data laporan keuangan seperti neraca dan laba rugi dari PT Surya Semesta Internusa Tbk dengan melakukan perhitungan, pengukuran, dan mereview data keuangan. Teknik yang digunakan untuk mengukur data laporan keuangan adalah rasio dan du pont

Data yang digunakan pada penelitian ini adalah sumber data sekunder, data tersebut diambil publikasi dari situs resmi . Data laporan yang digunakan adalah Laporan Keuangan pada tahun 2014 - 2019 dan diambil pada situs resmi PT. Surya Semesta Internusa Tbk www.suryainternusa.com dan diperoleh dari Bursa Efek Indonesia yang diunduh melalui situs http://www.idx.co.id

\section{HASIL DAN PEMBAHASAN}

Berikut ini adalah hasil analisis laporan keuangan PT. Surya Semesta Internusa Tbk dan yang terd aftar di bursa efek ind onesia tahun 2014 -2019:

\section{Analisis Rasio}

Hasil dari analisis ratio pada laporan keuangan PT. Surya Semesta Internusa Tbk dan Industri ditunjukan pada tabel berikut:

Tabel 2 Analsis Ratio Keuangan

\begin{tabular}{|c|c|c|c|c|c|c|c|c|c|c|c|c|c|}
\hline \multirow{2}{*}{ Jenis Ratio } & \multirow{2}{*}{ Rumus } & \multicolumn{2}{|c|}{2014} & \multicolumn{2}{|c|}{2015} & \multicolumn{2}{|c|}{2016} & \multicolumn{2}{|c|}{2017} & \multicolumn{2}{|c|}{2018} & \multicolumn{2}{|c|}{2019} \\
\hline & & SSIA & $\begin{array}{c}\text { INDUST } \\
\text { RI }\end{array}$ & SSIA & $\begin{array}{c}\text { INDUST } \\
\text { RI }\end{array}$ & SSIA & $\begin{array}{c}\text { INDUST } \\
\text { RI }\end{array}$ & SSIA & $\begin{array}{c}\text { INDUST } \\
\text { RI }\end{array}$ & SSIA & $\begin{array}{c}\text { INDUST } \\
\text { RI }\end{array}$ & SSIA & $\begin{array}{c}\text { INDUST } \\
\text { RI }\end{array}$ \\
\hline \multicolumn{14}{|c|}{ RASIO LIKUIDITAS } \\
\hline Current Ratio & Aktiva Lancar & \multirow{2}{*}{1,68} & \multirow{2}{*}{1,31} & \multirow{2}{*}{1,56} & \multirow{2}{*}{1,38} & \multirow{2}{*}{1,78} & \multirow{2}{*}{1,42} & \multirow{2}{*}{1,93} & \multirow{2}{*}{1,25} & \multirow{2}{*}{1,70} & \multirow{2}{*}{1,35} & \multirow{2}{*}{2,37} & \multirow{2}{*}{1,25} \\
\hline (satuan:kali) & Utang Lancar & & & & & & & & & & & & \\
\hline & & & & & & & & & & & & & \\
\hline Quick Ratio & $\begin{array}{c}\text { Aktiva Lancar - } \\
\text { Persediaan }\end{array}$ & \multirow{2}{*}{1,48} & \multirow{2}{*}{1,20} & \multirow{2}{*}{1,31} & \multirow{2}{*}{1,28} & \multirow{2}{*}{1,58} & \multirow{2}{*}{1,30} & \multirow{2}{*}{1,77} & \multirow{2}{*}{1,15} & \multirow{2}{*}{1,47} & 120 & 212 & 110 \\
\hline (satuan:kali) & Utang Lancar & & & & & & & & & & $1, \angle 0$ & 2,12 & 1,10 \\
\hline & & & & & IO SOLVA & ITAS & & & & & & & \\
\hline Total Debt Ratio & $\begin{array}{c}\text { Total Aktiva - Total } \\
\text { Ekuitas } \\
\end{array}$ & 0.50 & 0.74 & 0.48 & 0.68 & 0.53 & 0.67 & 0.49 & 0.72 & 0.41 & 0.73 & 0.45 & \\
\hline (satuan:kali) & Total Aktiva & & & & & & & & & & & & 0,74 \\
\hline & & & & & & & & & & & & & \\
\hline Debt Equity Ratio & Total Utang & ०० & 283 & 0 & 213 & 115 & 190 & 009 & 252 & 069 & 273 & 081 & \\
\hline (satuan:kali) & Total Ekuitas & & & & & & & & & & & & 2,78 \\
\hline & & & & & & & & & & & & & \\
\hline Equality Multiplier & Total Aktiva & 1,99 & 3,83 & 1,94 & 3,13 & 2,15 & 2,99 & 1,98 & 3,52 & 1,69 & 3,73 & 1,81 & 378 \\
\hline (satuan:kali) & Total Ekuitas & & & & & & & & & & & & \\
\hline & & & & & & & & & & & & & \\
\hline Capital Structure & $\begin{array}{c}\text { Utang Jangka } \\
\text { Panjang }\end{array}$ & 0,42 & 0,54 & 0,38 & 0,50 & 0,58 & 0,47 & 0,39 & 0,62 & 0,22 & 0,87 & 0,42 & 0,97 \\
\hline (satuan:kali) & Total Ekuitas & & & & & & & & & & & & \\
\hline & & & & & TURNOI & ASET & & & & & & & \\
\hline Receivable Turn Over & Penjualan & & & & & & & & & & & & \\
\hline (satuan:kali) & Piutang & 9,51 & 5,36 & 11,56 & 4,33 & 7 & 4,62 & 10,23 & 6,54 & 4 & 5,90 & 8,69 & 5,13 \\
\hline & & & & & & & & & & & & & \\
\hline $\begin{array}{l}\text { Day's Sale in } \\
\text { Receivable }\end{array}$ & 365 hari & 38,40 & 68,05 & 31,58 & 84,30 & 27,3 & 78,96 & 35,66 & 55,85 & 33,9 & 61,81 & 41,9 & 71,22 \\
\hline
\end{tabular}




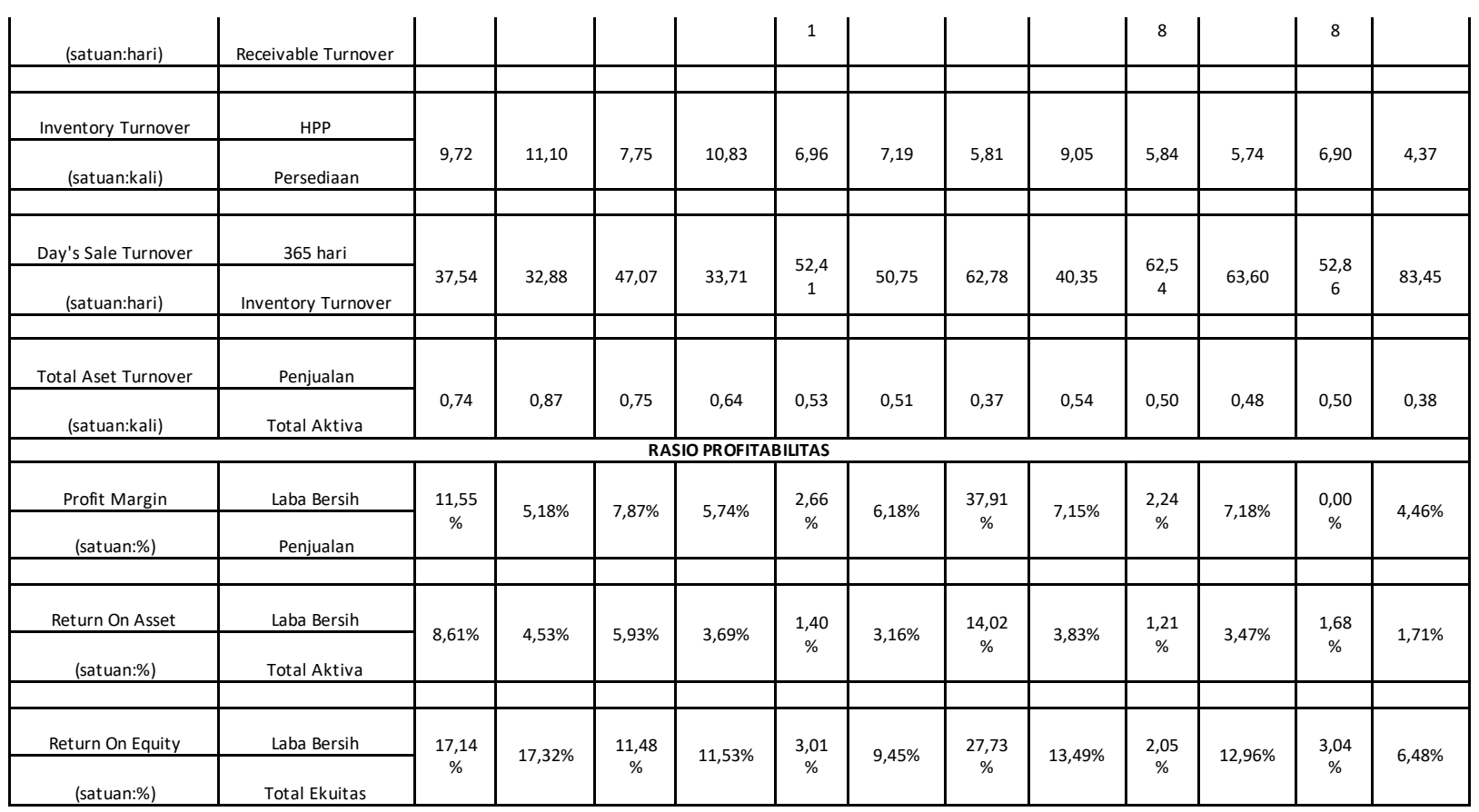

Sumber: LK Tahunan PT. Surya Semesta Internusa Tbk. dan Industri (https://www.idx.co.id)

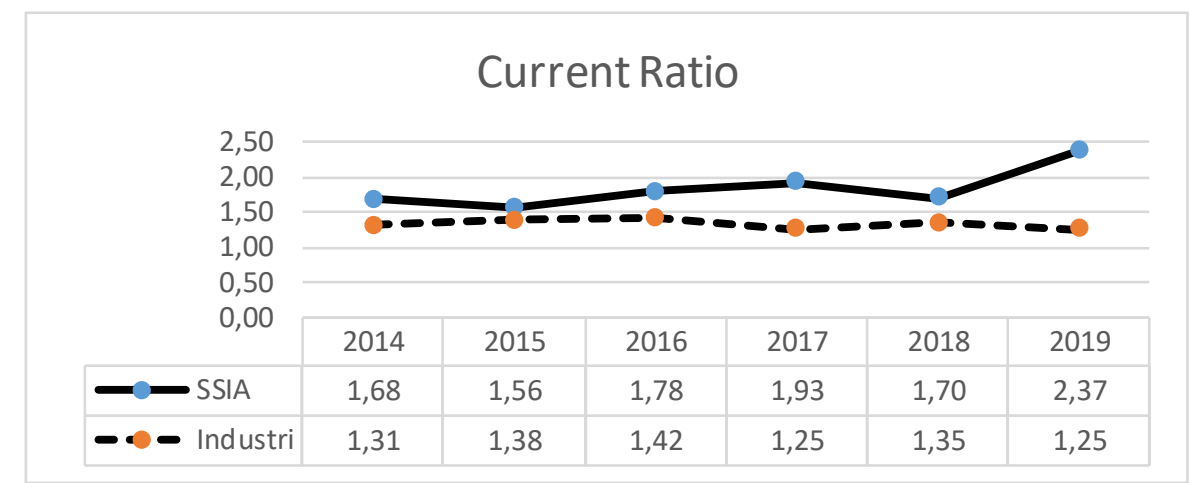

Grafik 1. Perbandingan Current Ratio SSIA dengan industri

Berdasarkan grafik diatas dapat dikatakan bahwa nilai current ratio PT. Surya Semesta Internusa Tbk. dengan total industri building construction bervariasi dari tahun ke tahun. untuk mendapatkan hasil current ratio yang lebih akurat dilakukan rata-rata nilai selama enam tahun dari tahun 2014 - 2019. Hasil rata-rata nilai current ratio PT. Surya Semesta Internusa Tbk.. sebesar 1,84 sedangkan nilai rata-rata industri building construction sebesar 1,33 .

Dalam current ratio yang memiliki nilai >1 yang menunjukkan bahwa perusahaan dianggap mampu memenuhi segala kewajiban jangka pendeknya. Apabila nilai current ratio $<1$ yang menunjukkan bahwa perusahaan dianggap tidak mampu memenuhi segala kewajiban jangka pendeknya. Dapat disimpulkan bahwa nilai current ratio PT. Surya Semesta Internusa Tbk.. berada pada posisi lebih tinggi di bandingkan dengan total industri building construction dan dapat dinyatakan bahwa PT. Surya Semesta Internusa Tbk. Lebih baik dari total ind ustri building construction 


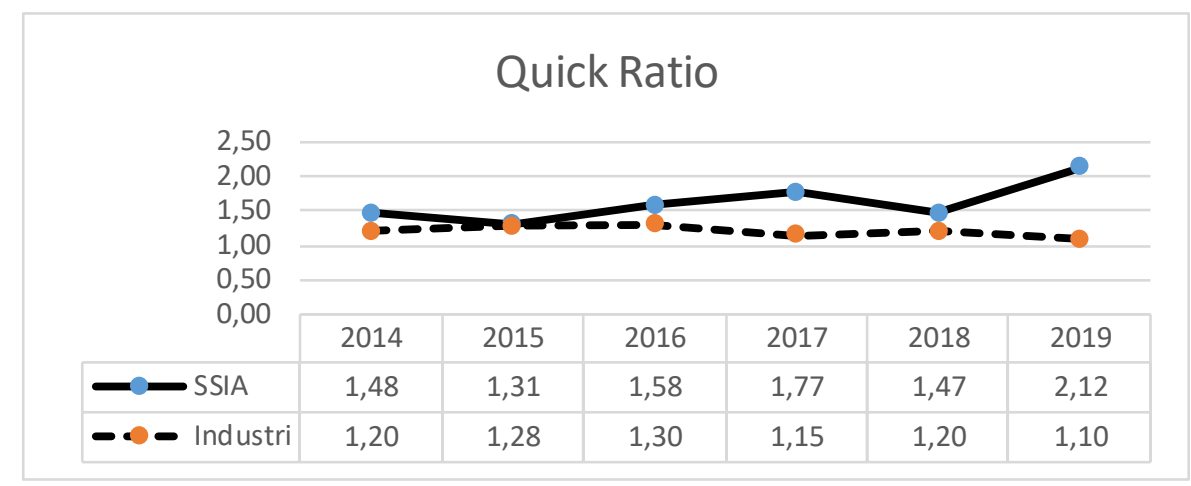

Grafik 2 Perbandingan Quick Ratio SSIA dengan Industri

Berdasarkan grafik diatas dapat dikatakan bahwa nilai quick ratio PT. Surya Semesta Internusa Tbk. dengan total industri building construction bervariasi dari tahun ke tahun. untuk mendapatkan hasil current ratio yang lebih akurat dilakukan rata-rata nilai selama enam tahun dari tahun 2014 - 2019. Hasil rata-rata nilai quick ratio PT. Surya Semesta Internusa Tbk. sebesar 1,62 sedangkan nilai rata-rata industri building construction sebesar 1,21 .

Dalam quick ratio yang memiliki nilai $>1$ yang menunjukkan bahwa perusahaan dianggap mampu memenuhi segala kewajiban jangka pendeknya. Apabila nilai quick ratio $<1$ yang menunjukkan bahwa perusahaan dianggap tidak mampu memenuhi segala kewajiban jangka pendeknya. Dapat disimpulkan bahwa nilai quick ratio PT. Surya Semesta Internusa Tbk.. berada pada posisi lebih tinggi di bandingkan dengan total industri building construction dan dapat dinyatakan bahwa PT. Surya Semesta Internusa Tbk. Lebih baik dari total ind ustri building construction

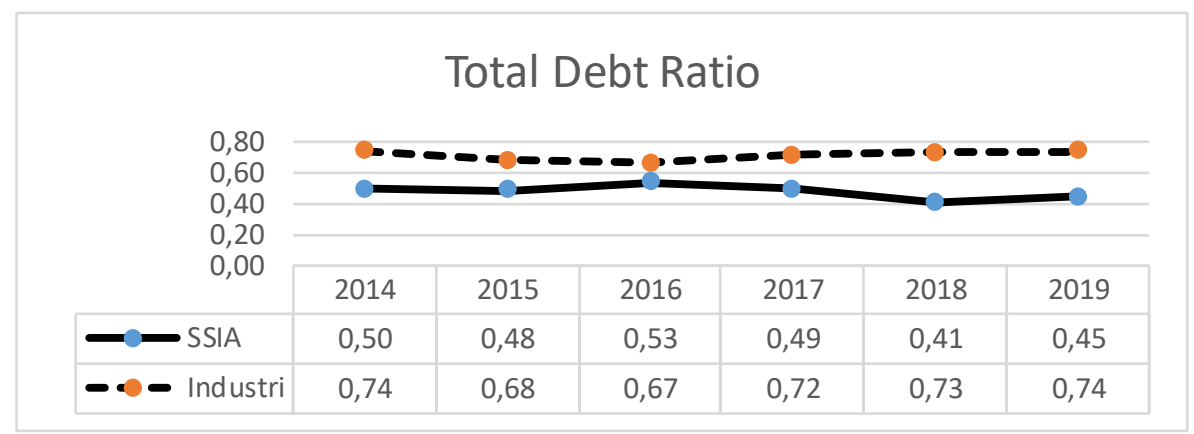

Grafik 3 Perbandingan Total Debt Ratio SSIA dengan Industri

Berdasarkan grafik diatas dapat dikatakan bahwa nilai total debt ratio PT. Surya Semesta Internusa Tbk. dengan total industri building construction bervariasi dari tahun ke tahun. untuk mendapatkan hasil current ratio yang lebih akurat dilakukan rata-rata nilai selama enam tahun dari tahun 2014 - 2019. Hasil rata-rata nilai total debt ratio PT. Surya Semesta Internusa Tbk. sebesar 0,48 sedangkan nilai rata-rata industri building construction sebesar 0,71. Dapat disimpulkan bahwa nilai total debt ratio PT. Surya Semesta Internusa Tbk.. berada pada posisi lebih rendah di bandingkan dengan total industri building construction dan dapat dinyatakan bahwa total industri building construction lebih baik dari PT. Surya Semesta Internusa Tbk 
Total debt ratio menunjukkan seberapa besar aktiva yang dimiliki oleh perusahaan yang dibiayai oleh hutang. Semakin besar nilai rasio, maka dapat diartikan aktiva yang dimiliki oleh perusahaan dibiayai atau dibeli dengan menggunakan hutang

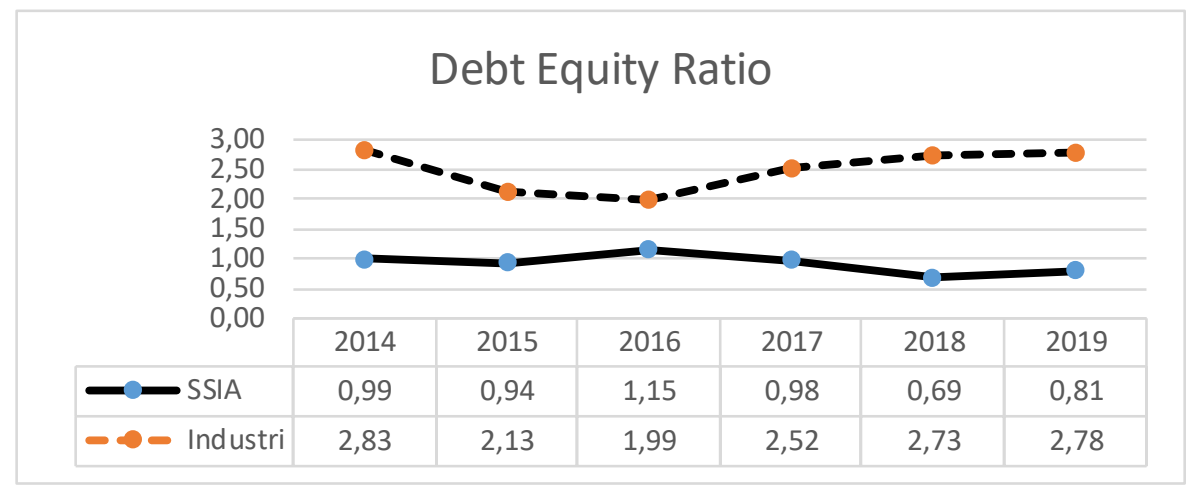

Grafik 4 Perbandingan Debt Equity Ratio SSIA dengan Industri

Berdasarkan grafik diatas dapat dikatakan bahwa nilai debt equity ratio PT. Surya Semesta Internusa Tbk. dengan total industri building construction bervariasi dari tahun ke tahun. untuk mendapatkan hasil debt equity ratio yang lebih akurat dilakukan rata-rata nilai selama enam tahun dari tahun 2014 - 2019. Hasil rata-rata nilai debt equity ratio PT. Surya Semesta Internusa Tbk. sebesar 0,92 sedangkan nilai rata-rata industri building construction sebesar 2,50. Dapat disimpulkan bahwa nilai debt equity ratio PT. Surya Semesta Internusa Tbk.. berada pada posisi lebih rendah di bandingkan dengan total industri building construction dan dapat dinyatakan bahwa total industri building construction lebih baik dari PT. Surya Semesta Internusa Tbk

Debt equity ratio menunjukkan seberapa besar ekuitas atau modal yang dimiliki oleh perusahaan yang dibiayai oleh hutang. Semakin besar nilai debt equity rasionya maka artinya aktiva yang dimiliki oleh perusahaan dibiayai atau dibeli dengan menggunakan hutang.

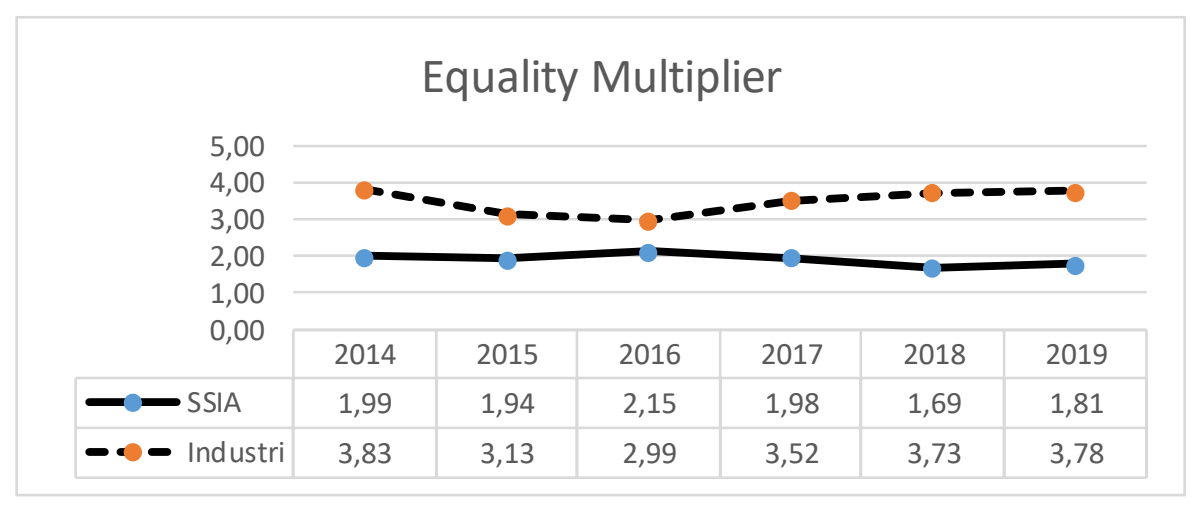

Grafik 5 Perbandingan Equality Multiplier SSIA dengan Industri

Berdasarkan grafik diatas dapat dikatakan bahwa nilai equiy multiplier PT. Surya Semesta Internusa Tbk. dengan total industri building construction bervariasi dari tahun ke tahun. untuk mendapatkan hasil equiy multiplier yang lebih akurat dilakukan rata-rata nilai 
selama enam tahun dari tahun 2014 - 2019. Hasil rata-rata nilai equiy multiplier PT. Surya Semesta Internusa Tbk. sebesar 1,92 sedangkan nilai rata-rata industri building construction sebesar 3,50. Dapat disimpulkan bahwa nilai equiy multiplier PT. Surya Semesta Internusa Tbk. berada pada posisi lebih rendah di bandingkan dengan total industri building construction dan dapat dinyatakan bahwa total industri building construction lebih baik dari PT. Surya Semesta Internusa Tbk

Equity multiplier dapat menunjukkan kemampuaan perusahaan dalam mendayagunakan ekuitas pemegang saham. Semakin besar nilai rasio maka dapat diartikan sebagai berapa porsi dari aktiva perusahaan yang dibiayai oleh pemengang saham.

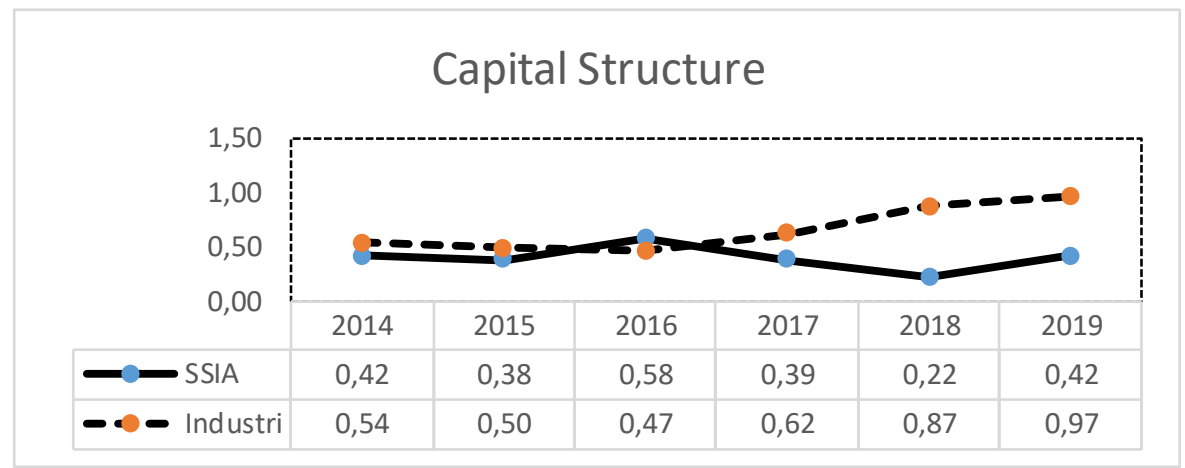

Grafik 6 Perbandingan Capital Structure SSIA dengan Industri

Berdasarkan grafik diatas dapat dikatakan bahwa nilai capital structure PT. Surya Semesta Internusa Tbk. dengan total industri building construction bervariasi dari tahun ke tahun. untuk mendapatkan hasil capital structure yang lebih akurat dilakukan rata-rata nilai selama enam tahun dari tahun 2014 - 2019. Hasil rata-rata nilai capital structure PT. Surya Semesta Internusa Tbk. sebesar 0,40 sedangkan nilai rata-rata industri building construction sebesar 0,66. Dapat disimpulkan bahwa nilai capital structure PT. Surya Semesta Internusa Tbk. berada pada posisi lebih rendah di bandingkan dengan total industri building construction dan dapat dinyatakan bahwa total industri building construction lebih baik dari PT. Surya Semesta Internusa Tbk

Capital Structure menunjukkan seberapa besar aset yang dimiliki perusahaan yang dibiayai atau berasal dari hutang jangka Panjang. Semakin besar nilai rasio, maka dapat dikatakan modal yang dimiliki perusahaan Sebagian besar berasal dari hutang jangka panjang

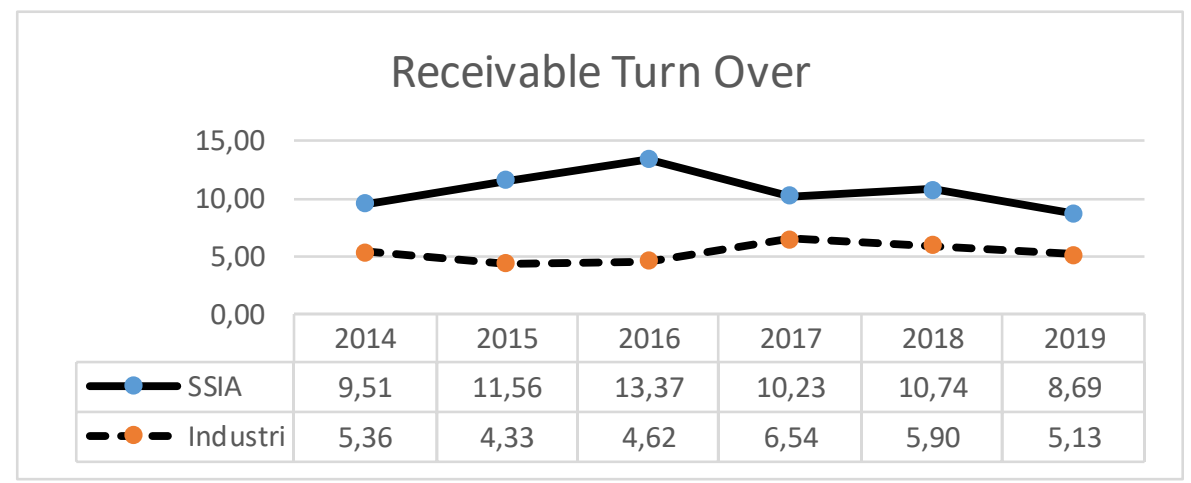




\section{Grafik 7 Perbandingan Receivable Turnover SSIA dengan Industri}

Berdasarkan grafik diatas dapat dikatakan bahwa nilai receivable turnover PT. Surya Semesta Internusa Tbk. dengan total industri building construction bervariasi dari tahun ke tahun. Untuk mendapatkan hasil receivable turnover yang lebih akurat dilakukan rata-rata nilai selama enam tahun dari tahun 2014 - 2019. Hasil rata-rata nilai receivable turnover PT. Surya Semesta Internusa Tbk. sebesar 10,68 sedangkan nilai rata-rata industri building construction sebesar 5,31. Dapat disimpulkan bahwa nilai receivable turnover PT. Surya Semesta Internusa Tbk. berada pada posisi lebih tinggi di bandingkan dengan total industri building construction dan dapat dinyatakan bahwa PT. Surya Semesta Internusa Tbk lebih baik dari total ind ustri building construction

Receivable turnover menunjukkan berapa kali perputaran piutang dapat berputar dalam setahun. Semakin tinggi nilai rasio receivable turnover pada perusahaan, maka piutang yang dapat ditagih oleh perusahaan semakin tinggi.

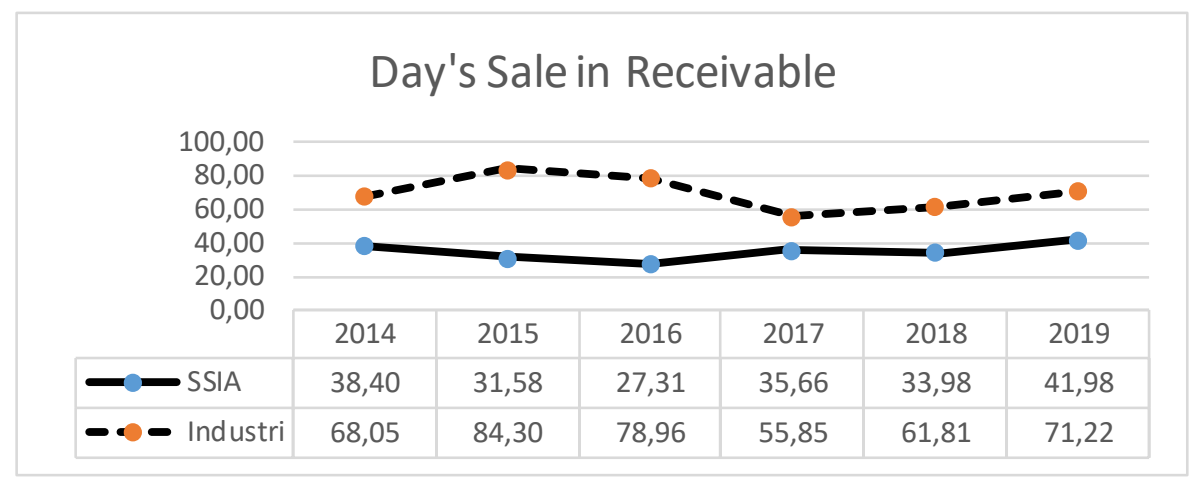

Grafik 8 Perbandingan Day's Sale In Receivable SSIA dengan Industri

Berdasarkan grafik diatas dapat dikatakan bahwa nilai Day's Sale In Receivable PT. Surya Semesta Internusa Tbk. dengan total industri building construction bervariasi dari tahun ke tahun. Untuk mendapatkan hasil Day's Sale In Receivable yang lebih akurat dilakukan rata-rata nilai selama enam tahun dari tahun 2014 - 2019. Hasil rata-rata nilai Day's Sale In Receivable PT. Surya Semesta Internusa Tbk. sebesar 34,82 sedangkan nilai rata-rata industri building construction sebesar 70,03. Dapat disimpulkan bahwa nilai Day's Sale In Receivable PT. Surya Semesta Internusa Tbk. berada pada posisi lebih rendah di bandingkan dengan total industri building construction dan dapat dinyatakan bahwa total ind ustri building construction lebih baik dari PT. Surya Semesta Internusa Tbk

Day's sale in receivable menunjukkan berapa lama rata-rata waktu yang dibutuhkan perusahaan untuk menagih setiap piutang yang tertagih. Semakin kecil nilai rasio day's sale in receivable, maka semakin cepat piutang dapat dilunasi. 


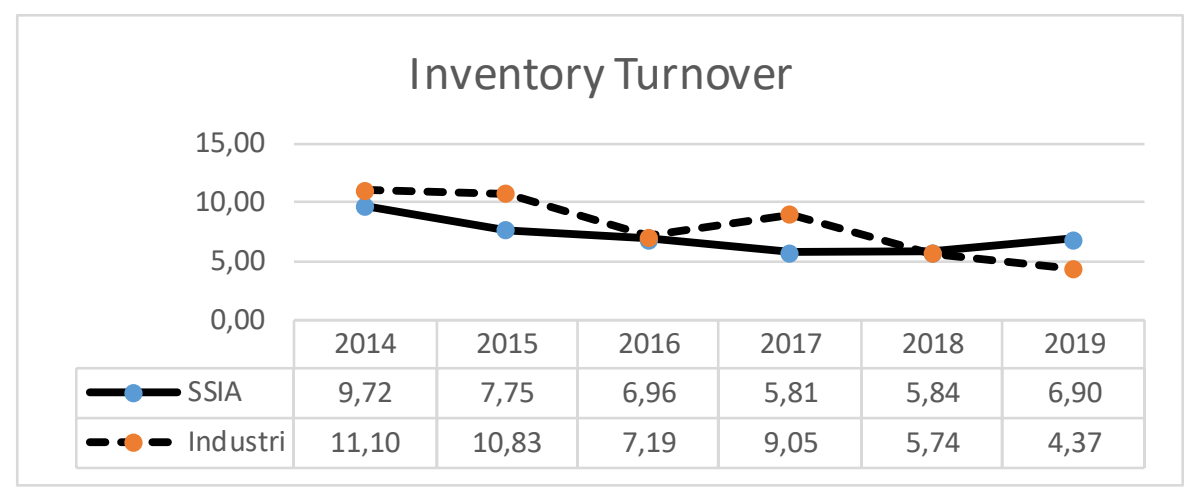

. Grafik 9 Perbandingan Inventory Turnover SSIA dengan Industri

Berdasarkan grafik diatas dapat dikatakan bahwa nilai Inventory Turnover PT. Surya Semesta Internusa Tbk. dengan total industri building construction bervariasi dari tahun ke tahun. Untuk mendapatkan hasil Inventory Turnover yang lebih akurat dilakukan rata-rata nilai selama enam tahun dari tahun 2014 - 2019. Hasil rata-rata nilai Inventory Turnover PT. Surya Semesta Internusa Tbk. sebesar 7,17 sedangkan nilai rata-rata industri building construction sebesar 8,05. Dapat disimpulkan bahwa nilai Inventory Turnover PT. Surya Semesta Internusa Tbk. berada pada posisi lebih rendah di bandingkan dengan total industri building construction dan dapat dinyatakan bahwa total industri building construction lebih baik dari PT. Surya Semesta Internusa Tbk

Inventory turnover menunjukkan berapa kali perputaran persediaan dapat berputar dalam waktu satu tahun atau dapat juga dikatakan rasio ini menunjukkan tingkat efisiensi dan efektifitas dari persediaan.

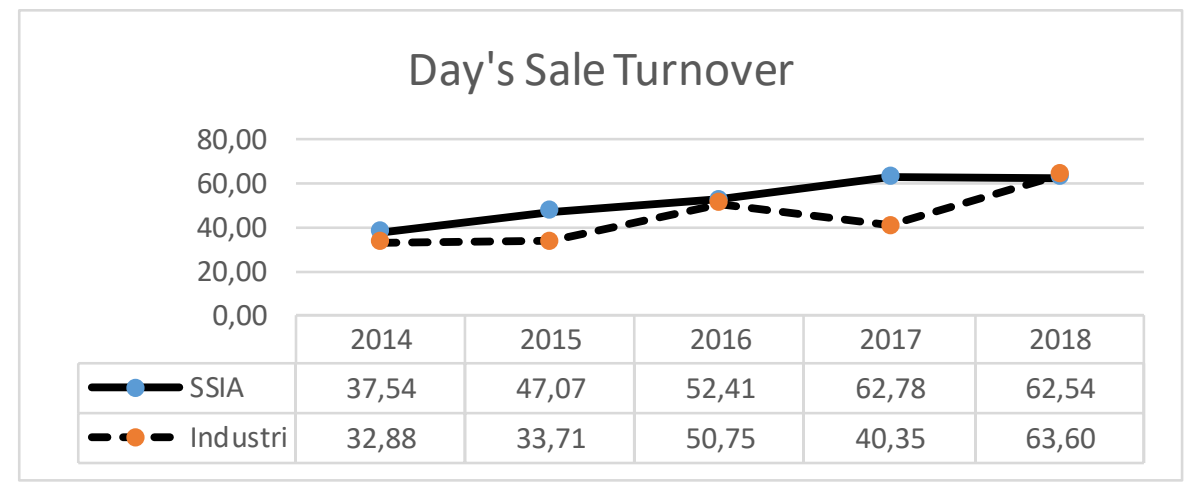

Grafik 10 Perbandingan Day's Sale Turnover SSIA dengan Industri

Berdasarkan grafik diatas dapat dikatakan bahwa nilai Day's Sale Turnover PT. Surya Semesta Internusa Tbk. dengan total industri building construction bervariasi dari tahun ke tahun. Untuk mendapatkan hasil Day's Sale Turnover yang lebih akurat dilakukan rata-rata nilai selama enam tahun dari tahun 2014 - 2019. Hasil rata-rata nilai Day's Sale Turnover PT. Surya Semesta Internusa Tbk. sebesar 52,53 sedangkan nilai rata-rata industri building construction sebesar 50,79. Dapat disimpulkan bahwa nilai Day's Sale Turnover PT. Surya Semesta Internusa Tbk. berada pada posisi lebih rendah di bandingkan dengan 
total industri building construction dan dapat dinyatakan bahwa PT. Surya Semesta Internusa Tbk lebih baik dari total industri building construction

Day's Sale Turnover menunjukkan berapa lama waktu yang dibutuhkan perusahaan untuk menyimpan persediaan mereka sebelum dijual dan juga dikatakan bahwa rasio ini dapat menunjukkan berapa lama waktu yang dibutuhkan untuk menjual persediaan yang tersedia di perusahaan

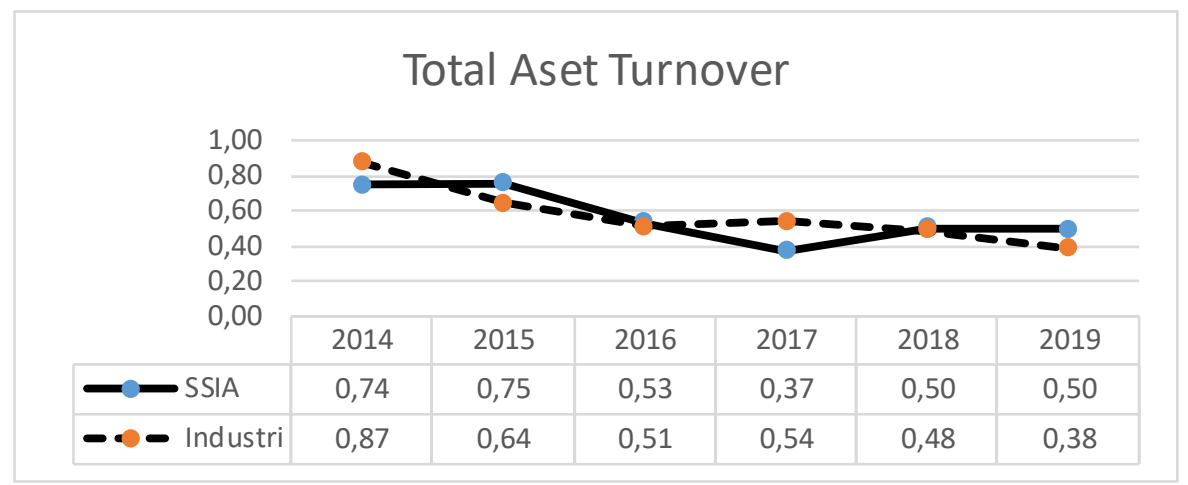

Grafik 11 Perbandingan Total Asset Turnover SSIA dengan Industri

Berdasarkan grafik diatas dapat dikatakan bahwa nilai Total Asset Turnover PT. Surya Semesta Internusa Tbk. dengan total industri building construction bervariasi dari tahun ke tahun. Untuk mendapatkan hasil Total Asset Turnover yang lebih akurat dilakukan rata-rata nilai selama enam tahun dari tahun 2014 - 2019. Hasil rata-rata nilai Total Asset Turnover PT. Surya Semesta Internusa Tbk. sebesar 0,57 sedangkan nilai rata-rata industri building construction sebesar 0.57. Dapat disimpulkan bahwa nilai Total Asset Turnover PT. Surya Semesta Internusa Tbk. berada pada posisi yang sama dengan total industri building construction dan dapat dinyatakan bahwa PT. Surya Semesta Internusa Tbk sama baiknya dengan total industri building construction

Total asset turnover menunjukkan kemampuan perusahaan dalam mengelola seluruh asset yang dimilikinya untuk menghasilkan penjualan. Semakin tinggi total asset turnover maka semakin tinggi pula penjualan yang dilakukan oleh perusahaan.

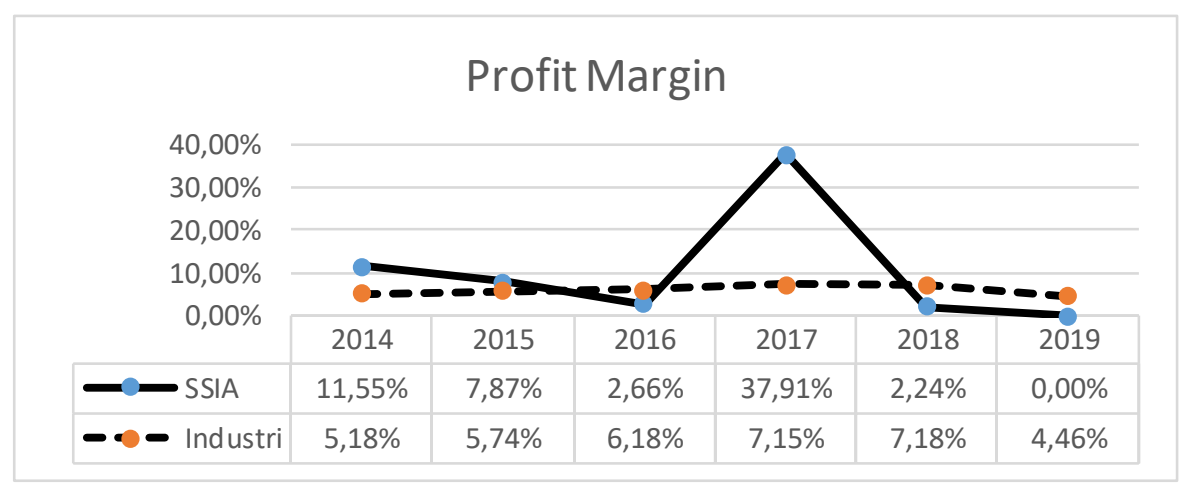

Grafik 12 Perbandingan Profit Margin SSIA dengan Industri

Berdasarkan grafik diatas dapat dikatakan bahwa nilai Profit Margin PT. Surya Semesta Internusa Tbk. dengan total industri building construction bervariasi dari tahun ke tahun. Untuk mendapatkan hasil Profit Margin yang lebih akurat dilakukan rata-rata nilai 
selama enam tahun dari tahun 2014 - 2019. Hasil rata-rata nilai Profit Margin PT. Surya Semesta Internusa Tbk. sebesar $10,37 \%$ sedangkan nilai rata-rata industri building construction sebesar 5,98\%. Dapat disimpulkan bahwa nilai Profit Margin PT. Surya Semesta Internusa Tbk. berada pada posisi yang lebih tinggi dibandingkan dengan total industri building construction dan dapat dinyatakan bahwa PT. Surya Semesta Internusa Tbk lebih baik dibandingkan dengan total industri building construction

Profit margin menunjukkan kemampuan seberapa besar keuntungan yang akan diperoleh perusahaan dari aktivitas penjualan. Semakin tinggi nilai profit margin maka akan semakin tinggi pula laba yang dihasilkan perusahaan.

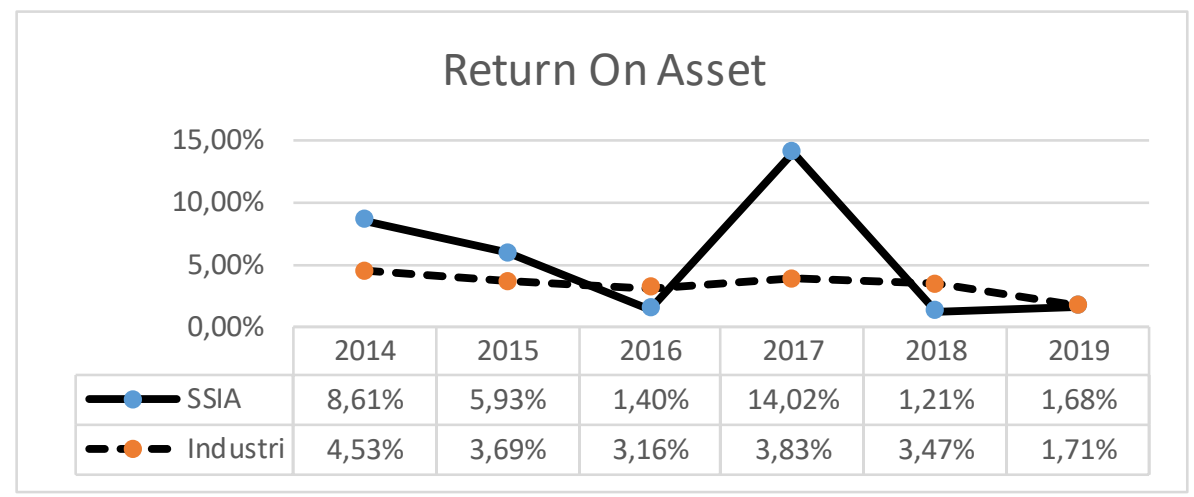

Grafik 13 Perbandingan Return On Asset SSIA dengan Industri

Berdasarkan grafik diatas dapat dikatakan bahwa nilai Return On Asset PT. Surya Semesta Internusa Tbk. dengan total industri building construction bervariasi dari tahun ke tahun. Untuk mendapatkan hasil Return On Asset yang lebih akurat dilakukan rata-rata nilai selama enam tahun dari tahun 2014 - 2019. Hasil rata-rata nilai Return On Asset PT. Surya Semesta Internusa Tbk. sebesar 5,48\% sedangkan nilai rata-rata industri building construction sebesar 3,40\%. Dapat disimpulkan bahwa nilai Return On Asset PT. Surya Semesta Internusa Tbk. berada pada posisi yang lebih tinggi dibandingkan dengan total industri building construction dan dapat dinyatakan bahwa PT. Surya Semesta Internusa Tbk lebih baik dibandingkan dengan total industri building construction

Return on asset menunjukkan seberapa besar perushaan memperoleh keuntungan yang dihasilkan perusahaan dari asset yang dimiliki Semakin tinggi nilai return on asset maka semakin tinggi pula laba yang dihasilkan perusahaan

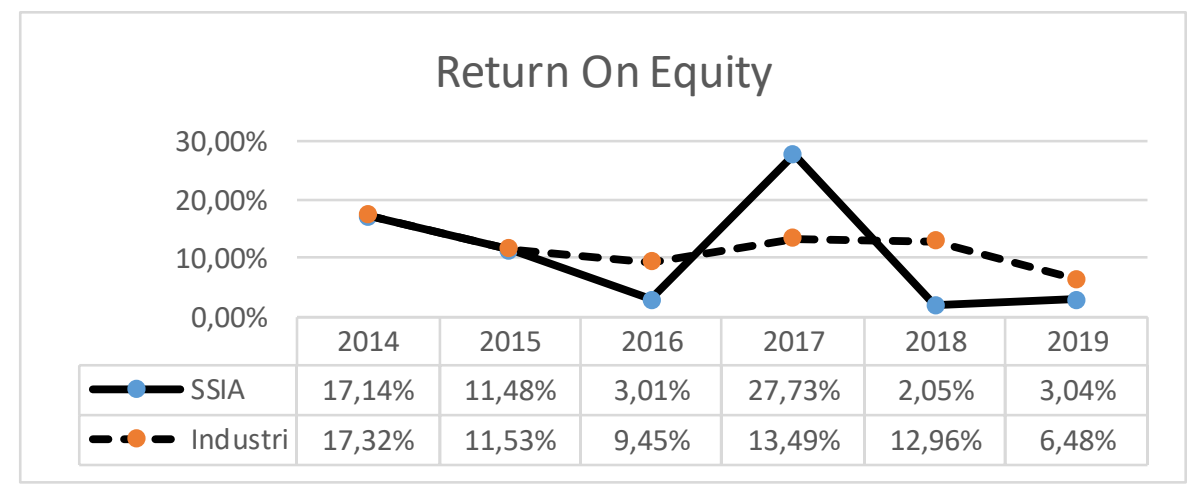

Grafik 14 Perbandingan Return On Equity SSIA dengan Industri 
Berdasarkan grafik diatas dapat dikatakan bahwa nilai Return On Equity PT. Surya Semesta Internusa Tbk. dengan total industri building construction bervariasi dari tahun ke tahun. Untuk mendapatkan hasil Return On Equity yang lebih akurat dilakukan rata-rata nilai selama enam tahun dari tahun 2014 - 2019. Hasil rata-rata nilai Return On Equity PT. Surya Semesta Internusa Tbk. sebesar $10,74 \%$ sedangkan nilai rata-rata industri building construction sebesar 11,87\%. Dapat disimpulkan bahwa nilai Return On Equity PT. Surya Semesta Internusa Tbk. berada pada posisi yang lebih rendah dibandingkan dengan total industri building construction dan dapat dinyatakan bahwa total industri building construction lebih baik dibandingkan dengan PT. Surya Semesta Internusa Tbk

Return on equity menunjukkan seberapa besar perushaan memperoleh keuntungan dari ekuitas atau modal yang dimiliki. Semakin tinggi nilai return on equity maka semakin tinggi pula laba yang dihasilkan perusahaan

\section{Analisis Du Pont}

Hasil dari analisis Du Pont pada laporan keuangan PT. Surya Semesta Internusa Tbk dan Industri ditunjukan pada tabel berikut:

Tabel 3 Analisis Du Pont

\begin{tabular}{|c|c|c|c|c|c|c|c|c|c|c|c|c|}
\hline \multirow{2}{*}{ Jenis Ratio } & \multicolumn{2}{|c|}{2014} & \multicolumn{2}{|c|}{2015} & \multicolumn{2}{|c|}{2016} & \multicolumn{2}{|c|}{2017} & \multicolumn{2}{|c|}{2018} & \multicolumn{2}{|c|}{2019} \\
\hline & SSIA & INDUSTRI & $\begin{array}{l}\text { SSIA } \\
\end{array}$ & INDUSTRI & SSIA & INDUSTRI & $\begin{array}{l}\text { SSIA } \\
\end{array}$ & INDUSTRI & SSIA & INDUSTRI & SSIA & INDUSTRI \\
\hline Profit Margin & $11,55 \%$ & $5,18 \%$ & $7,87 \%$ & $5,74 \%$ & $2,66 \%$ & $6,18 \%$ & $37,91 \%$ & $7,15 \%$ & $2,24 \%$ & $7,18 \%$ & $0,00 \%$ & $4,46 \%$ \\
\hline $\begin{array}{c}\text { Total Aset } \\
\text { Turnover }\end{array}$ & 0,74 & 0,87 & 0,75 & 0,64 & 0,53 & 0,51 & 0,37 & 0,54 & 0,50 & 0,48 & 0,50 & 0,38 \\
\hline $\begin{array}{c}\text { Equality } \\
\text { Multiplier }\end{array}$ & 1,99 & 3,83 & 1,94 & 3,13 & 2,15 & 2,99 & 1,98 & 3,52 & 1,69 & 3,73 & 1,81 & 3,78 \\
\hline $\begin{array}{l}\text { ROE Analisis } \\
\text { DuPont }\end{array}$ & $17,14 \%$ & $17,32 \%$ & $11,48 \%$ & $11,53 \%$ & $3,01 \%$ & $9,45 \%$ & $27,73 \%$ & $13,49 \%$ & $1,89 \%$ & $12,96 \%$ & $0,00 \%$ & $6,48 \%$ \\
\hline
\end{tabular}

Sumber: Laporan Keuangan Tahunan PT. Surya Semesta Internusa Tbk. (Https://www.idx.co.id)

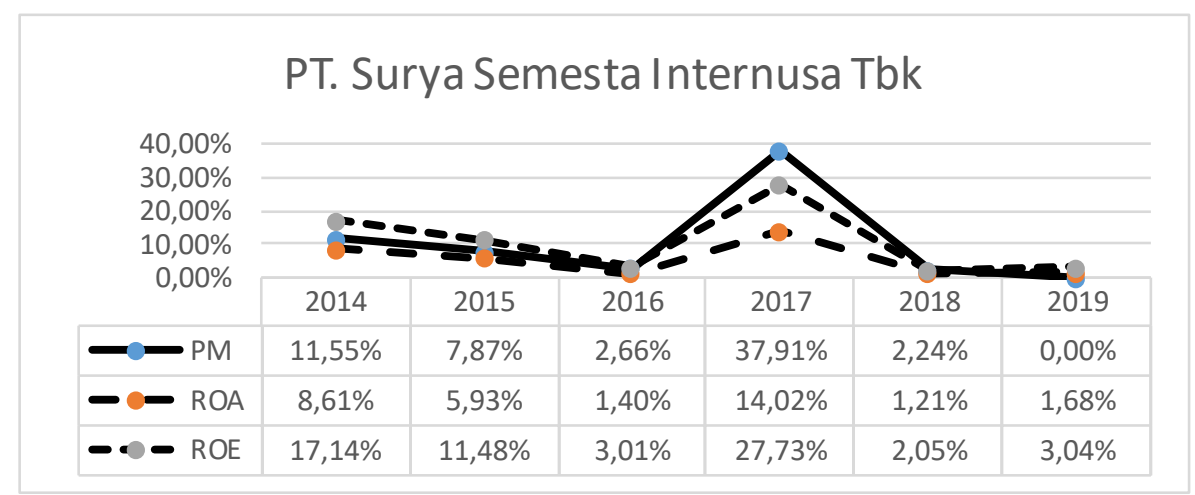

Grafik 15 Perbandingan Profit Margin, Return On Asset, \& Return On Equity SSIA

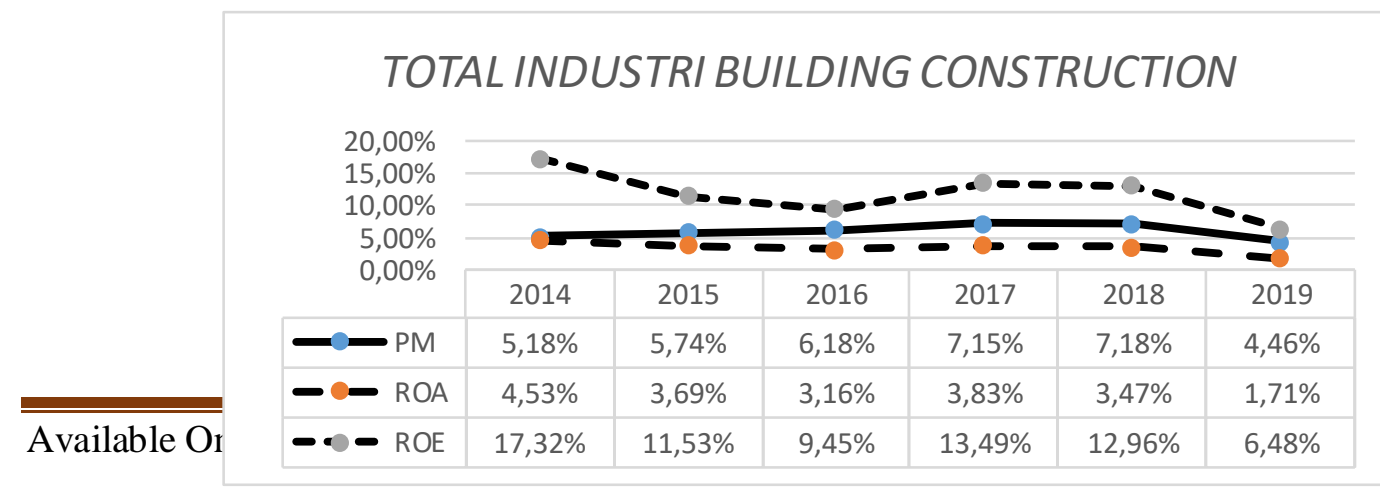

Page 393 


\section{Grafik 16 Perbandingan Profit Margin, Return On Asset, \& Return On Equity Industri}

Berdasarkan grafik 15 dan 16 diatas dapat dikatakan bahwa nilai Profit Margin, Return On Asset, \& Return On Equity PT. Surya Semesta Internusa Tbk. dengan total industri building construction bervariasi dari tahun ke tahun. Untuk mendapatkan hasil Profit Margin, Return On Asset, \& Return On Equity yang lebih akurat dilakukan rata-rata nilai selama enam tahun dari tahun 2014 - 2019. Hasil rata-rata nilai Profit Margin, Return On Asset, \& Return On Equity PT. Surya Semesta Internusa Tbk. sebesar 8,86\% sedangkan nilai rata-rata industri building construction sebesar 7,08\%. Dapat disimpulkan bahwa nilai Profit Margin, Return On Asset, \& Return On Equity PT. Surya Semesta Internusa Tbk. berada pada posisi yang lebih tinggi dibandingkan dengan total industri building construction dan dapat dinyatakan bahwa PT. Surya Semesta Internusa lebih baik dibandingkan dengan Tbk total industri building construction

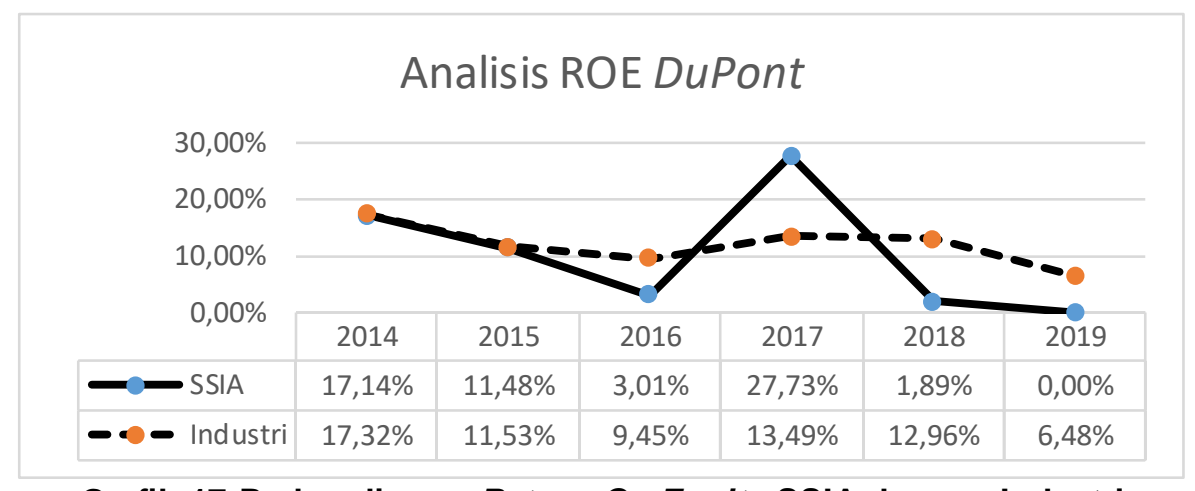

Grafik 17 Perbandingan Return On Equity SSIA dengan Industri

Berdasarkan grafik diatas dapat dikatakan bahwa nilai ROE DuPont PT. Surya Semesta Internusa Tbk. dengan total industri building construction bervariasi dari tahun ke tahun. Untuk mendapatkan hasil ROE DuPont yang lebih akurat dilakukan rata-rata nilai selama enam tahun dari tahun 2014 - 2019. Hasil rata-rata nilai ROE DuPont PT. Surya Semesta Internusa Tbk. sebesar 10,21\% sedangkan nilai rata-rata industri building construction sebesar 11,87\%. Dapat disimpulkan bahwa nilai ROE DuPont PT. Surya Semesta Internusa Tbk. berada pada posisi yang lebih rendah dibandingkan dengan total industri building construction dan dapat dinyatakan bahwa total industri building construction lebih baik dibandingkan dengan PT. Surya Semesta Internusa Tbk

\section{KESIMPULAN DAN SARAN}

Hasil penelitian keseluruhan dengan menggunakan analisis ratio dan analisis DuPont menunjukkan bahwa industri building construction lebih baik di bandingkan PT. Surya Semesta Internusa Tbk, hal ini terlihat dari beberapa hasil yang menunjukan bahwa industri building construction lebih mengungguli di bandingkan PT. Surya Semesta Internusa Tbk

Dalam penelitian ini analisis rasio dan analisis $d u$ pont, perusahaan harus tetap menstabilkan rasio-rasio keuangan sehingga perusahaan mampu mempertahankan kualitas permodalan maupun pemberian kreditnya, selain itu PT. Surya Semesta Internusa Tbk harus memperbaiki dan mengevaluasi kinerja keuangannya agar rasio keuangannya lebih baik di bandingkan industri 
PT. Surya Semesta Internusa dan industri building construction juga harus mempertahankan keseimbangan kinerja keuangan agar tidak menimbulkan masalah pada perusahaan

\section{DAFTAR RUJUKAN}

Fahmi, Irhami. 2014. Analisa Kinerja Keuangan. Bandung : Alfabeta

Fraser, L. M., \& Ormiston, A. 2018. Memahami Laporan Keuangan. Jakarta : Indeks.

Harahap, S.S .2013. Analisis Kritis Atas Laporan Keuangan. Raja Grafindo Persada. Jakarta. Jumingan. 2014. Analisis Laporan Keuangan. Jakarta: Media Grafika

Kasmir. 2013. Analisis Laporan Keuangan. Edisi Pertama. Cetakan keenam. Rajawali Pers. Jakarta.

Kasmir. 2016. Analisis Laporan Keuangan. Edisi Pertama. Cetakan Kesembilan. Rajawali. Jakarta.

Keown, Arthur J., John D. Martin, J. William Petty, dan David F. Scott Jr. 2018.

Manajemen Keuangan: Prinsip dan Penerapan, Edisi ke-10, Cetakan ke-3, Jilid 1, PT Indeks.

Kieso, Weygandt, dan Warfield. (2011). Akuntansi Intermediate. Edisi Kedua Belas, Erlangga, Jakarta.

Najmudin. (2011). Manajemen Keuangan dan Akuntansi Syar'iyyah Modern. Yogyakarta: Andi Offset. 